\title{
Does the economic crisis contribute to the burnout and engagement of Spanish nurses?
}

\author{
Guadalupe Manzano García ${ }^{1}$ (D) $\cdot$ Ma $^{\text {Pilar Montañés Muro }}{ }^{1}$ (D) - Jesús López Megías ${ }^{2}$ (D) \\ Accepted: 19 February 2021 / Published online: 6 March 2021 \\ (C) The Author(s), under exclusive licence to Springer Science+Business Media, LLC part of Springer Nature 2021
}

\begin{abstract}
The national and European economic crisis has caused significant changes in the National Health System in Spain, among others a considerable deterioration in the working conditions of nursing professionals. The aim of this study was to analyse whether the economic crisis situation influenced the burnout and engagement of Spanish nursing professionals. The research design was a transversal study based on descriptive and inferential statistical analysis. Because the variable "economic crisis" is not susceptible to direct experimental manipulation, to explore its possible influence on the burnout and engagement of nursing staff, we use an indirect strategy of "priming". That is, we presented a group of participants with news about how the economic crisis was affecting healthcare personnel, in order to facilitate their cognitive accessibility, while another control group did not read any news. The participants were 66 nursing professionals from two public hospitals in the north of Spain completed various questionnaires that allowed information to be collected on the factors of interest in the study. The work experience of the participants contributes significantly to their burnout levels. The economic crisis situation helps to explain the burnout of Spanish nurses, but not their engagement levels.
\end{abstract}

Keywords Economic crisis $\cdot$ Burnout $\cdot$ Engagement $\cdot$ Nursing $\cdot$ Work experience

\section{Introduction}

In a European context, and particularly in Spain, the economic crisis has conditioned the employment situation of nursing staff, causing, among other effects, a decrease in the rate of recruitment of these professionals. This has resulted in active personnel having to attend a larger number of patients. According to the 2015 and 2017 "Health at a Glance" reports prepared by the Organisation for Economic Co-operation and Development (OECD), Spain has one of the lowest ratios of nursing professionals per 1000 inhabitants of the European Union (EU) and a long way from the average (5.1 compared

Guadalupe Manzano García

guadalupe.manzano@unirioja.es

$\mathrm{M}^{\mathrm{a}}$ Pilar Montañés Muro

maria-pilar.montanes@unirioja.es

Jesús López Megías

jlmegias@ugr.es

1 Department of Sciences Education, University of La Rioja, C/ San José de Calasanz s/n, 26004 Logroño, Spain

2 Department of Social Psychology, University of Granada, Campus Universitario de Cartuja, 18071 Granada, Spain to 9.0 in 2013 and 5.3 compared to 9.0 in , 2015). Despite the fact that in the latest report published by the OECD "Health Statistics 2019," the ratio of nursing professionals has improved from 5.5 in 2016 to 5.7 in , 2017 (last year analysed), these figures are still far from the European average (estimated at 8.8 nurses per 1000 inhabitants). The economic crisis has had an impact on nursing professionals, meaning that, from 2010 onwards, those responsible for the Spanish Healthcare System used the situation to reduce human and material resources as an immediate saving measure. This situation generated, among other things, a work overload for healthcare professionals, more demanding performance targets, a proliferation of part-time temporary contracts and salary reductions and worsening of their already precarious work/life balance (Calero Romero, 2012). In other words, there has been an increase in occupational psychosocial risks (Moreno-Jiménez, 2011), the deterioration of healthcare professionals' well-being and the care they provide (SATSE, 2012). In addition, these organisational changes in the national health system, together with the reduction in public expenditure, labour market reforms and the increase in unemployment among Spanish nursing professionals, are generating an increase in the emigration of these professionals to other European countries (Galbany-Estragués \& Nelson, 2016). 
As has happened in other European countries, the economic crisis has led to an increase in job demands for Spanish nursing staff (Carta et al., 2017), demands that on many occasions have not been accompanied by an increase in the job resources. According to Bakker, Demerouti, and Sanz-Vergel (2014), this fact may have led to an increase in burnout and a decrease in engagement amongst this group of professionals.

Nursing itself is considered a stressful profession because it requires handling high emotional, cognitive, and physical demands (McVicar, 2003). Continued exposure to these demands is associated with stress, burnout, and fatigue (Garrosa, Moreno-Jimenez, Liang, \& Gonzalez, 2008), among other mental and physical problems (Hakanen \& Schaufeli, 2012; Oates, Drey, \& Jones, 2017). The nursing collective is the largest group among health professionals, playing a very important role in the quality of care and patient safety (Aiken et al., 2012).

It is known that the nursing profession, as a consequence of these and other labour problems, suffers from a relevant prevalence of what is known as burnout syndrome (Carod-Artal \& Vázquez-Cabrera, 2013). This syndrome is a response to prolonged exposure to work-related stress, and it negatively affects the people who suffer from it, the organisations and the health service recipients (Maslach \& Leiter, 2008), causing negative effects on job performance (Bakker et al., 2014).

Burnout has been defined as a negative indicator of workrelated well-being, including negative attitudes towards work (Bakker et al., 2014). The main dimensions of this syndrome are emotional exhaustion (feeling of being emotionally and physically exhausted) and cynicism (response of excessive detachment and negativity towards work), together with the feeling of reduction of personal achievements (low perception of competence and achievement) (Bakker, 2016).

Recent studies indicate that health professionals report very high burnout rates (Wahlberg, Nirenberg, \& Capezuti, 2016), and specifically in the Spanish context (Aiken et al., 2012; Fuentelsaz-Gallego et al. 2012). Burnout conditions hospital performance due to increased staff turnover intentions (Leiter \& Maslach, 2009), staff absenteeism (Davey, Cummings, Newburn-Cook, \& Lo, 2009) or early retirement intentions (Linzer et al., 2001).

In contrast, engagement is defined as a positive emotional state associated with work and characterised by high levels of vigour, dedication, and absorption (Schaufeli \& Bakker, 2004; Schaufeli, Salanova, González-Romá, \& Bakker, 2002). Vigour refers to high levels of energy and resilience, even when difficulties and obstacles to work arise. Dedication is related to high labour participation, associated with the expression of a feeling that implies meaning, enthusiasm, pride in work and inspiration (Schaufeli \& Bakker, 2004). Finally, absorption arises when individuals are fully concentrated on their work and time "flies", with difficulties in disconnecting from what they are doing
(Schaufeli \& Bakker, 2004). Although there are discrepancies on how to conceptualise engagement at work, it is widely accepted that this committed work is exhibited with a high level of energy, vigour and identification (Bakker, Albrecht, \& Leiter, 2011). The energy and enthusiasm that is characteristic of work engagement can act as an energetic resource that will help health professionals mobilize new resources in their work environment.

Previous research has shown that engagement spreads among colleagues and improves their performance. For example, Bakker and Xanthopoulou (2009) showed that employees who communicate regularly at work influence others in terms of strength, dedication and absorption at work (see also Bakker, Emmerik, \& Euwema, 2006). In short, engagement gives rise to an enthusiastic positive work-related state of mind (Demerouti \& Bakker, 2011), becoming an indicator of well-being in itself and therefore a component of a motivational process related to resources and positive organisational outcomes, such as performance (Schaufeli \& Taris, 2014).

As Schaufeli and Bakker (2004) or Halbesleben (2010) have shown, working conditions are the main predictors of both burnout and engagement. However, while job resources are the most significant predictors of work engagement, job demands are the most important predictors of burnout. In a study carried out between 2017 and 2018 with a sample of 1335 Spanish professional nurses, when asked "do you consider that the economic crisis in Spain has a negative impact on their working conditions? $99.1 \%$ considered that the economic crisis had had a negative influence on their working conditions. (Gómez, Vara, \& Sánchez 2019). Besides, in a recent correlational research with a sample of nursing students (ManzanoGarcía, Montañés, \& Megías, 2017) they found that the perception of this economic crisis on the part of nursing students was positively related to the burnout and negatively with the commitment to their studies. Thus, the main objective of this work is to explore whether the serious economic crisis in which Spain has been immersed in recent years, a crisis that has led to significant economic adjustments in the healthcare sector, could influence the development of burnout or engagement in nursing staff. More specifically, our hypotheses are:

- H1: The economic crisis is positively related to burnout.

- H2: The economic crisis is negatively related to engagement.

This study improves on previous research into burnout and literature on engagement by analysing its relationship with a little-studied situational variable: the economic crisis. This study also provides authorities and health managers with information that allows them to better understand the impact that the economic crisis has had on nursing staff's wellbeing and commitment. 


\section{Methods}

\section{Experiment Protocol}

In the present study, the possible relationship between the economic crisis, burnout and engagement in active nursing professionals is explored by means of an experimental design. Because the economic crisis is not susceptible to direct experimental manipulation, to explore its possible influence on burnout and engagement, we use an indirect priming strategy. To this end, we presented to half of the participants a real news item from the Ánimo de Enfermería magazine (a free magazine dedicated to postgraduate training in nursing and medicine), in which the General Assembly of the Organización Colegial de Enfermería (the regulatory body and competent authority of the profession in Spain) highlighted "the seriousness with which nursing is going through" and that "at present nurses are, without a doubt and by a very wide margin, the main victims of the crisis in the health sector and this is having a serious impact on the care provided and the patient's safety."

In one of the experimental conditions, the participants $(n=$ 31) read the following news:

\section{CTO MAGAZINE.}

NURSING.

A few weeks ago, the Organización Colegial de Enfermería' general assembly, which brings together all the presidents of the country's profession, once again showed the seriousness of the nursing experience.

The Assembly of presidents of said organisation has revealed in a press release that nurses are, without any doubt and with a great deal of difference, the main victims of the health sector crisis and this is resulting seriously in the care provided and in the safety of the patients.

We present this news as a way to boost the cognitive accessibility of the crisis and thus be able to study its possible effect on burnout and engagement. The other participants $(n=$ 35) completed the burnout and engagement questionnaires without having read any news. Thus, following the same logic as other research (Schwarz \& Strack, 1981), if there is a relationship between the crisis and the burnout and/or engagement, we should find higher burnout and lower engagement scores in the condition where the participants had previously read the news about the crisis than in the condition where they had not read it.

We carried out two hierarchical regression analysis, in order to examine the role that the economic crisis plays in explaining burnout and nursing staff engagement. In the first step of the regression analysis, control variables were introduced, and in the second step the experimental condition was introduced (news: 1 vs no news: 0 ). The validity of the models analysed was evaluated according to the $\mathrm{R}^{2}$, the adjusted $\mathrm{R}^{2}$ and the F-test of statistical significance. Analysis of the quantitative data was performed using Statistical Package for Social Sciences, IBM (2015).

\section{Measures}

The following scales and measuring instruments were used in the study:

- Questionnaire on socio-demographic variables.

At the beginning of the questionnaire, participants were asked to provide information on their age, sex, nationality, professional experience, number of dependants and number of children.

- Utrecht Work Engagement Scale (UWES) (Schaufeli \& Bakker, 2003).

Engagement was assessed through the Spanish adaptation of the UWES (Salanova, Schaufeli, Llorens, Peiró \& Grau, 2000) composed of 17 items distributed in three subscales: 1) vigour (6 items, e.g., "In my work I feel full of energy"), 2) dedication (6 items, e.g., "My work makes sense") and 3) absorption (5 items, e.g., "When I am working I forget everything that's happening around me"). As a response measure, a seven-point Likert scale was used (from $0=$ "never" to $6=$ "always"). Cronbach's alphas were $0.74,0.74$ and 0.86 respectively. The internal consistency of the scale as a whole was 0.85 .

- Maslach Burnout Inventory General Survey (MBI-GS) (Schaufeli, Leiter, Maslach, \& Jackson, 1996).

Burnout was measured using the Spanish adaptation of the MBI-GS, consisting of 16 items distributed in 3 subscales: 1) exhaustion (5 items, e.g., "I feel tired of my work"), 2) cynicism (5 items, e.g., "I have become less enthusiastic about my work") and 3) professional effectiveness ( 6 items, e.g., "I feel confident that I am effective at doing things"). All items are scored on a seven-point Likert scale, ranging from 0 ("never") to 6 ("every day"). Cronbach's alphas were $0.81,0.67$ and 0.79 respectively. The internal consistency of the scale as a whole was 0.75 .

This study respects the Helsinki World Declaration on biomedical research with human subjects. The researchers visited the hospital units, requesting the participation of the professionals. The surveys were given to professionals who agreed to participate without compensation and with prior informed consent. The questionnaire was delivered in an envelope to preserve the anonymity of the participants; it included a cover letter indicating that a study was being carried out with the nursing staff. The confidentiality and anonymity of the participants was guaranteed. 


\section{Control Variables}

Several studies conducted in recent years with samples of nursing professionals have linked a number of sociodemographic variables with both burnout and engagement. The variables most commonly studied were the age of the professional and the years of professional practice. In relation to both it seems that the data is inconclusive, and sometimes even the results found are contradictory. For example, in terms of age and engagement, Cadiz (2011) found that they were positively related, while Walker and Campbell (2013) found no such relationship. Similarly, with regard to the relationship between age and burnout, various investigations report contradictory data. Some find a negative correlation between age and burnout (Fortunatti \& Palmeiro-Silva, 2017), for example, in research by Gómez-Urquiza, Vargas, De la Fuente, Fernández-Castillo, and Cañadas-De la Fuente (2017) where it was found that, the younger the age, the greater the emotional exhaustion and the depersonalisation of the nursing staff. However, other studies have reported lower burnout levels in nurses under 30 years of age compared to those over that age (Losa Iglesias \& Becerro de Bengoa, 2010). Finally, in some papers they find no relationship between age and burnout (Kiekkas, Spyratos, Lampa, Aretha, \& Sakellaropoulos, 2010). Some authors consider that the years in which professionals would be most vulnerable to burnout would be the first years of their professional career, since that would be the transition from their expectations to the working practice and they would verify the inadequacy of these expectations (Jiménez \& Puente, 1999), what Cherniss called "career start burnout".

As with the age variable, contradictory results are also found in studies which relate the years of professional experience and engagement. Some report a positive relationship between years of nursing practice experience and professional engagement (Bamford, Wong, \& Laschinger, 2013; Rivera, Fitzpatrick, \& Boyle, 2011), while other studies report a negative relationship (Sullivan Havens, Warshawsky, \& Vasey, 2013) or even no relationship (Simpson, 2009). In relation to burnout and years of professional experience, there is no agreement between researchers; some authors find no relationship between the syndrome and experience in the profession (Moreno et al., 2003), others find a positive relationship between experience and burnout (eg, Salillas, 2017), while finally, some studies indicate that more experienced nurses have significantly less burnout than less experienced nurses (eg, Breen \& Sweeney, 2013; Mollart, Skinner, Newing, \& Foureur, 2013); this may be due to the fact that the staff with the most burnout end up abandoning their careers and therefore those with the most years of service have the least burnout (Naisberg-Fennig, Fennig, Keinan, \& Elizur, 1991).

\section{Participants}

A total of 66 nursing professionals from two Spanish public hospitals participated (100\% response rate). The age of the participants ranged from 22 to 62 years $(M=40.38$, DT $=$ 10.95). Almost the entire sample consisted of women (65 women and 1 man). Regarding marital status, $27.7 \%$ of the participants were single, compared to $58.5 \%$ of married people, $6.2 \%$ divorced and $7.7 \%$ common-law couples. Years of experience in the profession ranged from 1 year to 40 years of professional practice $(M=17.82)$. Regarding the type of contract, $66.2 \%$ said they had a fixed contract compared to $26.2 \%$ of eventual contracts, $7.7 \%$ marked the option of others. $42.2 \%$ worked less than $40 \mathrm{~h}$ a week, $34.4 \% 40 \mathrm{~h}$ a week and $23.4 \%$ worked more than $40 \mathrm{~h}$. As for the number of children, $47.7 \%$ did not have any, $16.9 \%$ had one child, $33.8 \%$ had two children and $1.5 \%$ had three or more.

\section{Results}

First, the correlations of the sociodemographic variables with the variables of interest were calculated. As can be seen in Table 1, age and work experience correlated positively with burnout, but not with engagement. Burnout and engagement correlated negatively with each other, as expected (Leiter \& Maslach, 2004; Maslach \& Leiter, 1997). Age and work experience correlated positively in an almost perfect way; previous works have pointed out the multicollinearity that can arise when using both together as predictor variables (Jiménez, 2002). For this reason, we will include in subsequent analyses only work experience as a predictor of the burnout.

In each of the regression models analysed, the value of the Durbin-Watson statistic takes values that are within the acceptable range (1.5 to 2.5 ). This means that there is no autocorrelation problem in the data. The condition index in all models is within the acceptable range (15-20). In all cases, the values of the variance inflation factor (VIF) remained below the recommended maximum value of around 5. This means that there is no multicollinearity problem in the regression models used in this study.

In the case of the burnout, the work experience predicted it in a significant way, $\beta=.25, \mathrm{t}=2.05, p<.05$, so that, the more work experience, the more burnout. In the second step of the regression, when experimental condition was introduced, $R^{2}$ increased by $7 \%(\mathrm{~F}=4,53 ; p=0,03)$. We also found significant effect of the condition $\beta=.26, t=2.13, p<.05$ so that, as we hypothesised, the burnout scores of the participants of the condition where the crisis became salient were higher than those of the participants of the control condition.

In relation to engagement, no significant effect was found either from work experience $\beta=-.08, t=-.62, p=n s$, or from 
Table 1 Study variables and relatives in charge

\begin{tabular}{|c|c|c|c|c|c|c|}
\hline & Age & Experience & $\mathrm{N}^{\circ}$ Children & Relatives in Charge & Burnout & Engagement \\
\hline Age & & $.946 * *$ & $.467 * *$ & $-.433 * *$ & $.254 *$ & -.056 \\
\hline Experience & & & $.389 * *$ & -.201 & $.256 *$ & -.080 \\
\hline $\mathrm{N}^{\circ}$ Children & & & & $-352 *$ & .012 & .055 \\
\hline Relatives in Charge & & & & & -.249 & -.015 \\
\hline Burnout & & & & & & $-.277 *$ \\
\hline Engagement & & & & & & 1 \\
\hline
\end{tabular}

** Significance level of $\mathrm{p}<0.01 . /$ * Significance level of $\mathrm{p}<0.05$

economic crisis, $\beta=-.03, t=-.24, p=n s$. These results allowed us to reject our $\mathrm{H} 2$ (The economic crisis is negatively related to engagement) (Fig. 1).

\section{Discussion}

The present study investigates the relationship between the economic crisis and the burnout and engagement of active Spanish nurses. The results indicate that prioritising information about the economic crisis leads to a greater perception of burnout among nursing staff. However, this same action does not change the engagement reported by Spanish nurses.

This result would partially confirm the results of the study by Manzano-García et al. (2017), in which the perception of economic crisis positively predicted the burnout and negatively predicted the engagement of nursing students. These differences between the results of the two studies could be due to differences in the designs between them, since the current study follows an experimental design and that of ManzanoGarcía et al. (2017) was correlational. Alternatively, it could be due to the differences between the samples, active professionals in this study and nursing students in the study by Manzano-García et al. (2017). It could be that the engagement of university students in relation to their studies depended on the perception of crisis, since this could negatively affect their integration into the labour market (a recurring concern among

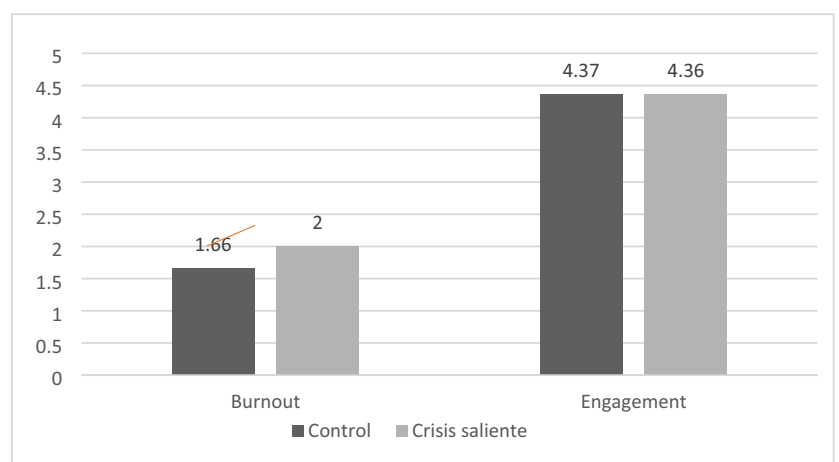

Fig. 1 Average scores in burnout and engagement according to the experimental condition students) and lead to less engagement in relation to their studies. But in the case of active professionals, the crisis may not determine their engagement because they are already incorporated into the labour market, and other variables more related to the content or meaning of the work determine it, such as, for example, the capacity for internal reward or whether or not patients recognize the importance of their work (GarcíaSierra, Fernández-Castro \& Martínez-Zaragoza, 2017). Previous studies have in fact found a relationship between the perceived importance of contributing to the lives of others and engagement (Freeney \& Tiernan, 2009). According to García-Sierra et al. (2017, pp. 153) "nurses who maintain high engagement are also affected by negative aspects, however, the appreciation of positive aspects such as enjoying work, the meaning of being a nurse, reward and autonomy allow them to overcome the engagement wear process". In any case, both studies have found a relationship between the economic crisis and the burnout in the Spanish context (H1), regardless of the differences between the samples.

The fact that the economic crisis has not contributed to explaining nursing staff's engagement $(\mathrm{H} 2)$ is an unexpected finding. As we have previously suggested, this may be because the job resources are necessary but not sufficient variables to explain nursing staff's engagement. It could also indicate that the economic crisis has considerably increased job demands but has not sufficiently eroded available job resources. Another explanation for this finding could be that there is a significant difference between the influence of the crisis itself and the perception of the crisis by participants. The finding that the level of engagement seems independent from that crisis is thought-provoking and merits more specific study in subsequent research projects.

In relation to years of professional experience, our results would confirm the relationship between years of professional practice and burnout, but not so with engagement. This result coincides with that of previous studies that find the same positive relationship of professional experience with burnout syndrome (eg, Salillas, 2017), but contradicts that of others in which no such relationship was found (eg, Moreno Jiménez, Trujillo Flores, Rivas Tovar, Lámbarry Vilchis, 2014) or a negative relationship was found (eg, Breen \& Sweeney, 
2013; Mollart et al., 2013). It should be mentioned in this sense that the average professional experience of the sample in this study has been close to 18 years, while in the previous literature it is indicated that it could be after 10 years when a period of awareness occurs in which workers would be more vulnerable to the syndrome. (Hillhouse \& Adler, 1997; cited by Albaladejo et al., 2004): "After this time of professional practice, there has already been a transition from idealistic expectations to everyday practice, with personal, professional and economic rewards being neither promised nor expected" (Albaladejo et al., 2004, pp. 513).

Given the possible consequences for the health system of burnout on active nursing staff, such as increased staff turnover intentions (Leiter \& Maslach, 2009), absenteeism (Davey et al., 2009) or early retirement intentions (Linzer et al., 2001), the results of this study would support the need to develop programmes and take measures to try to alleviate the effects of burnout and predict it on health professionals, even more so in contexts of economic crisis.

We are aware that our study has a number of limitations which should be corrected in future research. Firstly, in our research the sample was one of convenience, composed almost exclusively of women (although it is true that in Spain, as in most countries, the nursing profession is markedly feminised). Secondly, longitudinal studies should be carried out to allow a better understanding of the causes and effects of the economic crisis over time. Finally, it would be appropriate to replicate this study in other contexts of economic crisis. Despite these limitations, this work could inspire others to introduce situational variables (for example the crisis generated by COVID-19) in studies on burnout and engagement of nurses.

In conclusion, the most significant finding of this study is the confirmation that prioritising information about the economic crisis leads to a greater perception of burnout among Spanish nurses, but not of engagement. So, the context of economic crisis would be conditioning the burnout of these workers.

\section{Declarations}

This study respects the Helsinki World Declaration on biomedical research with human subjects.

Conflict of Interest On behalf of all authors, the corresponding author states that there is no conflict of interest.

\section{References}

Aiken, L. H., Sermeus, W., Van den Heede, K., Sloane, D. M., Busse, R., McKee, M., et al. (2012). Patient safety, satisfaction, and quality of hospital care: cross sectional surveys of nurses and patients in 12 countries in Europe and the United States. British medical journal, 344, e1717. https://doi.org/10.1136/bmj.e1717.

Albaladejo, R., Villanueva, R., Ortega, P., Astasio, P., Calle, M. E., \& Domínguez, V. (2004). Síndrome de burnout en el personal de enfermería de un hospital de Madrid [burnout syndrome in the nursing staff of a Madrid hospital]. Revista Española de Salud Pública, $78,505-516$.

Bakker, A. B. (2016). Burnout. In Encyclopedia of Human Resource Management. Edward Elgar publishing limited. In: Wilkinson, a., Johnstone, S. (Eds), Edward Elgar, Cheltenham. pp. 36-37.

Bakker, A. B., \& Xanthopoulou, D. (2009). The crossover of daily work engagement: Test of an actor-partner interdependence model. Journal of Applied Psychology, 94(6), 1562-1571. https://doi.org/ 10.1037/a0017525.

Bakker, A. B., Albrecht, S. L., \& Leiter, M. P. (2011). Key questions regarding work engagement. European Journal of Work and Organizational Psychology, 20(1), 4-28. https://oi.org/10.1080/ 1359432x.2010.485352.

Bakker, A. B., Demerouti, E., \& Sanz-Vergel, A. I. (2014). Burnout and work engagement: The JD-R approach. Annual Review of Organizational Psychology and Organizational Behavior, 1, 389411. https://doi.org/10.1146/annurev-orgpsych-031413-091235.

Bakker, A. B., Emmerik, H. V., \& Euwema, M. C. (2006). Crossover of burnout and engagement in work teams. Work and Occupations, 33(4), 464-489. https://doi.org/10.1177/0730888406291310.

Bamford, M., Wong, C. A., \& Laschinger, H. (2013). The influence of authentic leadership and areas of worklife on work engagement of registered nurses. Journal of nursing management, 21(3), 529-540. https://doi.org/10.1111/j.1365-2834.2012.01399.X.

Breen, M., \& Sweeney, J. (2013). Burnout: The experiences of nurses who work in inner city areas. Mental Health Practice, 17(2), 12-20.

Cadiz, D.M. (2011). The effects of ageism climates and core selfevaluations on nurses' turnover intentions, organizational commitment, and work engagement. (Dissertation) Portland State University.

Calero Romero, M. R. (2012). Riesgos psicosociales en el personal de enfermería: Burnout [Psychosocial risk in nursing profession: Burnout]. Paper presented at En Interpsiquis 2012. 13 Congreso Virtual de psiquiatria.com, February 2012. Retrieved from http:// cdn.psiquiatria.com/bibliopsiquis/handle/10401/5268.

Carod-Artal, F. J., \& Vázquez-Cabrera, C. (2013). Burnout syndrome in an international setting. In S. Bährer-Kohler (Ed.), Burnout for experts: Prevention in the context of living and working (p. 15-35). Springer Science + Business Media. https://doi.org/10.1007/978-14614-4391-9 2.

Carta, M. G., Preti, A., Portoghese, I., Pisanu, E., Moro, D., Pintus, M., Pintus, E., Perra, A., D'Oca, S., Atzeni, M., Campagna, M., Pascolo, E. F., Sancassiani, F., Finco, G., D'Aloja, E., \& Grassi, L. (2017). Risk for depression, burnout and low quality of life among personnel of a University Hospital in Italy is a consequence of the impact one economic crisis in the welfare system? Clinical practice and epidemiology in mental health: $C P$ \& EMH, 13, 156-167. https:// doi.org/10.2174/1745017901713010156.

Davey, M. M., Cummings, G., Newburn-Cook, C. V., \& Lo, E. A. (2009). Predictors of nurse absenteeism in hospitals: A systematic review. Journal of Nursing Management, 17(3), 312-330. https:// doi.org/10.1111/j.1365-2834.2008.00958.x.

Demerouti, E., \& Bakker, A. B. (2011). The job demands-resources model: Challenges for future research. SA Journal of Industrial Psychology, 37(2), 1-9. https://doi.org/10.4102/sajip.v37i2.974.

Fortunatti, C. P., \& Palmeiro-Silva, Y. K. (2017). Effort-reward imbalance and burnout among ICU nursing staff: A cross-sectional study. Nursing Research, 66(5), 410-416. https://doi.org/10.1097/NNR. 0000000000000239.

Freeney, Y., \& Tiernan, J. (2009). Exploration of the Facilitators of and Barriers to Work Engagement in Nursing. International Journal 
Nursing Studies, 46, 1557-1565. https://doi.org/10.1016/j.ijnurstu. 2009.05.003.

Fuentelsaz-Gallego, C., Moreno-Casbas, T., López-Zorraquino, D., Gómez-García, T., \& González-María, E. (2012). Percepción del entorno laboral de las enfermeras españolas en los hospitales del sistema nacional de salud [Perception of the work environment of Spanish nurses in the hospitals of the national health system]. Enfermería. Clínica, 22(5), 261-268. https://doi.org/10.1016/j. enfcli.2012.09.001.

Galbany-Estragués, P., \& Nelson, S. (2016). Migration of Spanish nurses 2009-2014. Underemployment and surplus production of Spanish nurses and mobility among Spanish registered nurses: A case study. International. Journal. Nursing. Studies, 63, 112-123. https://doi. org/10.1016/j.ijnurstu.2016.08.013.

García Sierra, R., Fernández de Castro, J., \& Martínez Zaragoza, F.A. (2017). Implicación de las enfermeras en su profesión. Un estudio cualitativo sobre el engagement [Involvement of nurses in their profession. A qualitative study about engagement] Enfermería Clínica, 27(3), 153-162.

Garrosa, E., Moreno-Jimenez, B., Liang, Y., \& Gonzalez, J. L. (2008). The relationship between socio-demographic variables, job stressors, burnout, and hardy personality in nurses: An exploratory study. International Journal of Nursing Studies, 45(3), 418-427. https://doi.org/10.1016/j.ijnurstu.2006.09.003.

Gómez, L. Á., Vara, P. M., \& Sánchez, M. C. G. (2019). Síndrome de burnout y satisfacción laboral en enfermeras españolas en tiempo de crisis económica [Burnout syndrome and job satisfaction in Spanish nurses in times of economic crisis] Metas de enfermería, 22(4), 78.

Gómez-Urquiza, J. L., Vargas, C., De la Fuente, E. I., Fernández-Castillo, R., \& Cañadas-De la Fuente, G. A. (2017). Age as a risk factor for burnout syndrome in nursing professionals: A meta-analytic study. Research in Nursing \& Health, 40(2), 99-110. https://doi.org/10. 1002/nur.21774.

Hakanen, J. J., \& Schaufeli, W. B. (2012). Do burnout and work engagement predict depressive symptoms and life satisfaction? A threewave seven-year prospective study. Journal of Affective Disorders, 141(2-3), 415-424. https://doi.org/10.1016/j.jad.2012.02.043.

Halbesleben, J. R. B. (2010). A meta-analysis of work engagement: Relationships with burnout, demands, resources, and consequences. In A. B. Bakker (Ed.) \& M. P. Leiter, work engagement: $A$ handbook of essential theory and research (p. 102-117). Psychology Press.

Hillhouse, J. J., \& Adler, C. M. (1997). Investigating stress effect patterns in hospital staff nurses: Results of a cluster analysis. Social Science \& Medicine, 45(12), 1781-1788.

IBM, 2015.IBM SPSS Statistics 22. IBM, Chicago, II.

Jiménez, B.M., \& Puente, C.P. (1999). El estrés asistencial en los servicios de salud [The stress of care in health services]. Manual de psicología de la salud: Fundamentos [Manual of health psychology: Fundamentals], Madrid: Biblioteca Nueva, pp. 739-757.

Kiekkas, P., Spyratos, F., Lampa, E., Aretha, D., \& Sakellaropoulos, G. C. (2010). Level and correlates of burnout among orthopaedic nurses in Greece. Orthopaedic Nursing, 29(3), 203-209. https:// doi.org/10.1097/NOR.0b013e3181db53ff.

Leiter, M., \& Maslach, C. (2004). Areas of worklife: A structured approach to organizational predictors of job burnout. En P.L. Perrewe, y D.C. Ganster (Eds.), Research in occupational stress and wellbeing (pp. 91-134). Oxford: Elsevier.

Leiter, M. P., \& Maslach, C. (2009). Nurse turnover: The mediating role of burnout. Journal of Nursing Management, 17(3), 331-339. https://doi.org/10.1111/j.1365-2834.2009.01004.x.

Linzer, M., Visser, M. R., Oort, F. J., Smets, E. M., McMurray, J. E., \& De Haes, H. C. (2001). Predicting and preventing physician burnout: Results from the United States and the Netherlands. The American Journal of Medicine, 111(2), 170-175.
Losa Iglesias, M. E., \& Becerro de Bengoa, R. (2010). Prevalence and relationship between burnout, job satisfaction, stress and clinical manifestations in Spanish critical care nurses. Dimensions Critical Care Nursing, 32, 130-137. https://doi.org/10.1097/DCC. 0b013e31828647fc.

Manzano-García, G., Montañés, P., \& Megías, J. L. (2017). Perception of economic crisis among Spanish nursing students: Its relation to burnout and engagement. Nurse Education Today, 52, 116-120. https://doi.org/10.1016/j.nedt.2017.02.020.

Maslach, C., \& Leiter, M. P. (2008). Early predictors of job burnout and engagement. Journal of Applied Psychology, 93(3), 498-512. https://doi.org/10.1037/0021-9010.93.3.498.

Maslach, C., Leiter, M. (1997). The truth about burnout. Jossey- Bass. https://trove.nla.gov.au/version/18742411

McVicar, A. (2003). Workplace stress in nursing: A literature review. Journal of Advanced Nursing, 44(6), 633-642. https://doi.org/10. 1046/j.0309-2402.2003.02853.x.

Mollart, L., Skinner, V. M., Newing, C., \& Foureur, M. (2013). Factors that may influence midwives work-related stress and burnout. Women and Birth, 26(1), 26-32. https://doi.org/10.1016/j.wombi. 2011.08.002.

Moreno, M. P., Bermúdez, D., Beltrán, C. A., Castellanos, J. P., Salinas, E. F., \& Pérez, G. A. (2003). Prevalencia de estrés y burnout en los trabajadores de la salud en un hospital ambulatorio [ prevalence of stress and burnout in health workers in an outpatient hospital]. Psicología y Salud, 13(1), 47-52.

Moreno-Jiménez, B. (2011). Factores y riesgos laborales psicosociales: conceptualización, historia y cambios actuales. Medicina y Seguridad del Trabajo, 57(Suppl. 1), 4-19.

Moreno Jiménez, J.C., Trujillo Flores, M., Rivas Tovar, L.A., \& Lámbarry Vilchis, F. (2014). Evolution of the Concept and Models of Work Exhaustion (Burnout): The Research in Mexico. International Business Research, 7(9), 45-66. https://doi.org/10. 5539/ibr.v7n9p45.

Naisberg-Fennig, S., Fennig, S., Keinan, G., \& Elizur, A. (1991). Personality characteristics and proneness to burnout: A study among psychiatrists. Stress Medicine, 7(4), 201-205.

Oates, J., Drey, N., \& Jones, J. (2017). Associations between age, years in post, years in the profession and personal experience of mental health problems in UK mental health nurses. Issues in Mental Health Nursing, 38(8), 624-632. https://doi.org/10.1080/ 01612840.2017 .1324927$.

OECD (2015), Health at a Glance 2015: OECD Indicators, OECD publishing, Paris, https://doi.org/10.1787/health glance-2015-en.

OECD (2017), Health at a Glance 2017: OECD Indicators, OECD publishing, Paris, https://doi.org/10.1787/health_glance-2017-en.

Rivera, R. R., Fitzpatrick, J. J., \& Boyle, S. M. (2011). Closing the RN engagement gap: Which drivers of engagement matter? JONA: The Journal of Nursing Administration, 41(6), 265-272. https://doi.org/ 10.1097/NNA.0b013e31821c476c.

Salanova, M., Schaufeli, W.B., Llorens, S., Peiró, J.M., \& Grau, R. (2000). Desde el «burnout» al «engagement»: ¿una nueva perspectiva? [From "burnout" to "engagement": a new perspective?]. Revista de Psicología del Trabajo y las Organizaciones, 16, 117-134.

Salillas, R. (2017). Síndrome de burnout en profesionales de enfermería en el ámbito hospitalario: Un estudio descriptivo [burnout syndrome in nursing professionals in the hospital setting: A descriptive study]. Enfermería del Trabajo, 7(3), 65-69.

SATSE (2012). Sindicato de enfermería. Crisis y estrés en profesionales de enfermería [Nursing union. Crisis and stress in nursing professionals]. Disponible en: http://www.satse.es/media/documentos/ informes/estudio-satse-percepcion-de-estres-en-los-profesionalesde-enfermeria-en-espana

Schaufeli W.B., \& Taris T.W. (2014). A critical review of the job demands-resources model: Implications for improving work and 
health. In Bridging Occupational, Organizational and Public Health A Transdisciplinary Approach. In: G.F. Bauer, O. Hammig (Eds), Springer science+business (pp. 43-68) Holland: Media Dordrecht. doi: https://doi.org/10.1007/978-94-007-5640-3_4.

Schaufeli, W. B., \& Bakker, A. B. (2004). Job demands, job resources, and their relationship with burnout and engagement: A multi-sample study. Journal of Organizational Behavior, 25(3), 293-315. https:// doi.org/10.1002/job.248.

Schaufeli, W. B., Leiter, M. P., Maslach, C., Jackson, S. E. (1996). The MBI general survey. In C. Maslach, S. E. Jackson, M. P. Leiter (Eds.), Maslach burnout inventory manual. Consulting Psychologists Press.

Schaufeli, W. B., Salanova, M., González-Romá, V., \& Bakker, A. B. (2002). The measurement of engagement and burnout: A two sample confirmatory factor analytic approach. Journal of Happiness studies, 3(1), 71-92. https://doi.org/10.1023/A:1015630930326.

Schaufeli, W.B., \& Bakker, A. B., 2003. UWES: Utrecht Work Engagement Scale.

Schwarz, N., \& Strack, F. (1981). Manipulating salience: Causal assessment in natural settings. Personality and Social Psychology Bulletin, 7(4), 554-558. https://doi.org/10.1177/014616728174005.
Simpson, M. R. (2009). Predictors of work engagement among medicalsurgical registered nurses. Western Journal of Nursing Research, 31(1), 44-65. https://doi.org/10.1177/0193945908319993.

Sullivan Havens, D., Warshawsky, N. E., \& Vasey, J. (2013). RN work engagement in generational cohorts: The view from rural US hospitals. Journal of Nursing Management, 21(7), 927-940. https://doi. org/10.1111/jonm.12171.

Wahlberg, L., Nirenberg, A., \& Capezuti, E. (2016). Distress and coping self-efficacy in inpatient oncology nurses. Oncology Nursing Forum, 43(6), 738-746. https://doi.org/10.1188/16.ONF.738-746.

Walker, A., \& Campbell, K. (2013). Work readiness of graduate nurses and the impact on job satisfaction, work engagement and intention to remain. Nurse Education Today, 33(12), 1490-1495. https://doi. org/10.1016/j.nedt.2013.05.008.

Publisher's Note Springer Nature remains neutral with regard to jurisdictional claims in published maps and institutional affiliations. 